\title{
Synthesis of 29-Hydroxy-3, 11-dimethyl-2-nonacosanone, Sex Pheromone of the German Cockroach ${ }^{\dagger}$
}

\author{
Ritsuo Nishida, Tetsuo Sato, Yasumasa Kuwahara, \\ Hiroshi Fukamm and Shoziro IsHII
}

Pesticide Research Institute, College of Agriculture, Kyoto University

Received March 15, 1976

\begin{abstract}
29-Hydroxy-3,11-dimethyl-2-nonacosanone, one component of the sex pheromone of the German cockroach, was synthesized. The synthetic compound was equivalent in the biological activity for the male to raise his wings to the natural one and was much more active than 3,11-dimethyl-2-nonacosanone which was another component of the pheromone.
\end{abstract}

From cuticular wax of sexually mature females of the German cockroach, Blattella germanica (L.), we have recently isolated two components of the sex pheromone which elicits wing-raising and direction-turning response from the male adults at the first stage of their sequential courtship behavior, and identified as 3,11-dimethyl-2-nonacosanone (the compound $\mathrm{A}, \mathrm{Ia})^{1,2}$ and 29-hydroxy-3,11dimethyl-2-nonacosanone (the compound $\mathrm{B}$, Ib) ${ }^{3}$ respectively, except absolute configurations at their asymmetric centers.

$$
\begin{gathered}
\mathrm{X}-\left(\mathrm{CH}_{2}\right)_{17}-\underset{!}{\mathrm{CH}}-\left(\mathrm{CH}_{2}\right)_{7}-\underset{\mathrm{CH}}{\mathrm{C}} \stackrel{\mathrm{CO}-\mathrm{CH}_{3}}{\mathrm{CH}_{3}} \\
\mathrm{Ia} ; \mathrm{X}=\mathrm{CH}_{3}- \\
\mathrm{Ib} ; \mathrm{X}=\mathrm{HOCH}_{2-}
\end{gathered}
$$

The syntheses of the compound A (Ia) have been reported by three research groups $s^{2,4 \sim 6)}$ and its several analogues have also been prepared to assess the effect of the structural modifications on the biological activity. ${ }^{6}$ We now report the synthesis of the compound $B$ (Ib) and its biological activity.

As shown in Fig. 1, 9-bromo-3-methyl-2nonanone (II) was converted to its ethylene ketal (III), which was subjected to the reaction with ethyl acetoacetate in a basic condition followed by alkaline hydrolysis and subsequent decarboxylation to give 11,11-ethylenedioxy10-methyl-2-dodecanone (IV). The reaction of this ketone with the Grignard reagent of 18bromoctadecanyl tetrahydro-2-pyranyl ether (V) produced the tertiary alcohol (VI) in which the desired carbon skeleton for the compound B was constructed. The alcohol (VI) was refluxed in ethyl methyl ketone in the presence of a catalytic amount of $p$-toluene

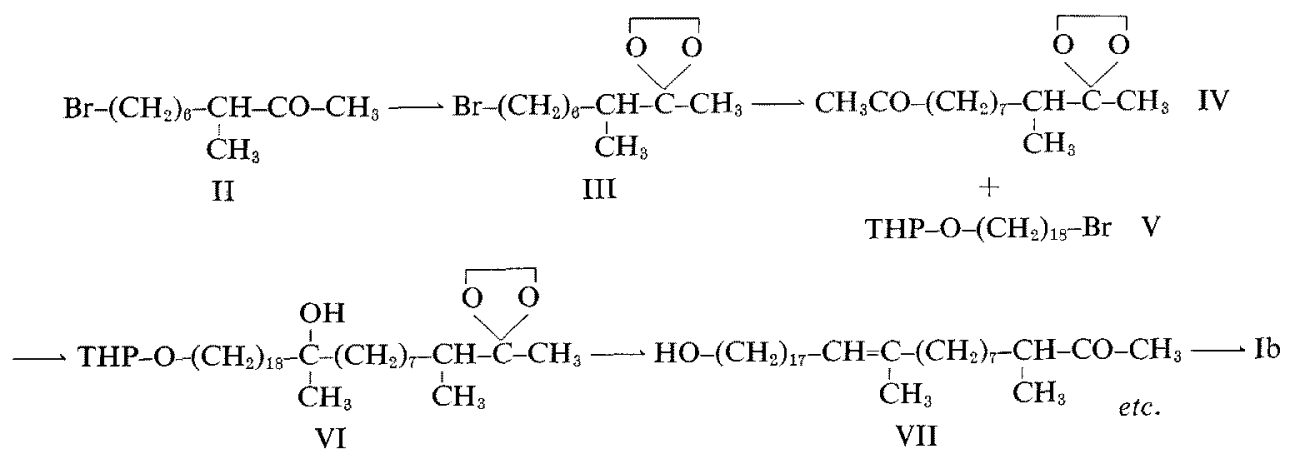

FIG. 1.

$\dagger$ Female Sex Pheromone of the German Cockroach, Blattella germanica (L.), Responsible for Male Wingraising. Part III. 


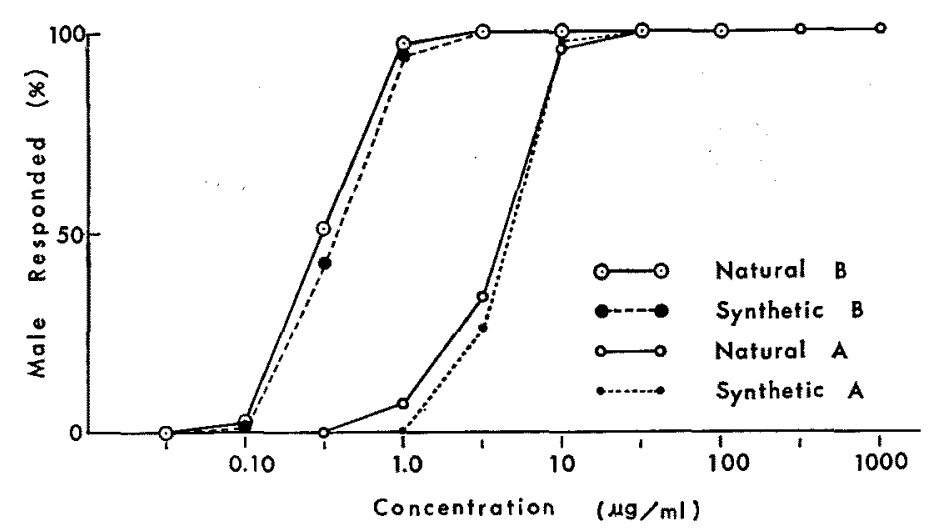

FrG. 2. Male Wing-raising Activities of the Natural and Synthetic Pheromones (the compound $A$ and B). The activity at each concentration is expressed by the mean value of more than 5 series of assay using each 10 test males.

sulfonic acid to dehydrate and to remove the ethylenedioxy group, and subsequently methanol was added into the reaction mixture and refluxed again to eliminate the tetrahydropyranyl group. The product was likely composed of positional olefinic isomers corresponding to the dehydro-compound $\mathrm{B}$, but it was, without any separation into each isomer, catalytically reduced to the synthetic compound $\mathrm{B}$ ( $\mathrm{Ib}$ ), which was identical in all respects of spectral (IR, NMR, and MS) and chromatographic (TLC, and GLC) data to the natural one. The melting point of the synthetic compound ( $\mathrm{mp} 40 \sim 41^{\circ} \mathrm{C}$ ) was, however, different from that of the natural one (mp $42 \sim 43^{\circ} \mathrm{C}$ ), ${ }^{3}$ presumably due to the configurational difference between them at two asymmetric carbon atoms (the 3- and 11position), because the natural one showed a positive optical rotation even though it was considerably small $\left([\alpha]_{\mathrm{D}}^{18}=+0.7^{\circ}, c=0.35\right.$ in hexane). ${ }^{3 \text { ) }}$

The biological activity for the wing-raising of the male German cockroach was evaluated by the same method as described in the previous papers. ${ }^{1,2,6)}$ Results of bioassay are shown in Fig. 2 and indicate that the synthetic compound $\mathbf{B}$ is as active as the natural one and their threshold concentration is around $0.1 \mu \mathrm{g} / \mathrm{ml}$. It is also noted that the concentration of the compound B for evoking $100 \%$ response of males is approximately one tenth of the compound A.

\section{EXPERIMENTAL}

Melting and boiling points were uncorrected. Spectral data were obtained with Shimadzu IR-400 spectrometer, Hitachi R-22 NMR spectrometer $(90 \mathrm{MHz})$, and Hitachi RMS-4 mass spectrometer. Gas liquid chromatograms were obtained with Yanaco GCG-550F gas chromatograph using a stainless steel column $(3 \mathrm{~mm}$ $\times 75 \mathrm{~cm}$ ) packed with $2 \%$ OV-17 on Chromosorb W $\left(60 \sim 80\right.$ mesh) at $220^{\circ} \mathrm{C}$ under helium flow rate $25 \mathrm{cc} /$ min.

\section{9-Bromo-3-methyl-2-nonanone (II)}

To potassium tert-butoxide solution (15 g of potassium dissolved in $300 \mathrm{ml}$ of tert-butyl alcohol) ethyl methylacetoacetate $(55 \mathrm{~g})$ was added, and then a large excess of 1,6-dibromohexane (148 $\mathrm{g}$ ) was added. The mixture was heated at $60 \sim 90^{\circ} \mathrm{C}$ for $4 \mathrm{hr}$ with stirring. The resultant mixture was evaporated, extracted with ether, washed with dilute hydrochloric acid and then with water, and dried over anhyd. sodium sulfate. Removal of the solvent and fractional distillation gave 9-bromo-3-carboethoxy-3-methyl-2-nonanone $(78 \mathrm{~g}$, $67 \%), \quad$ bp $148 \sim 158^{\circ} \mathrm{C} \quad(3 \mathrm{mmHg})$. IR $\sim_{\max }^{\mathrm{fl} 1 \mathrm{~m}} \mathrm{~cm}^{-1}$ : 1735, 1710. NMR $\delta_{\mathrm{TMS}}^{\mathrm{OCl} 1_{4}}: 4.13(2 \mathrm{H}, \mathrm{q}, J=7.0 \mathrm{~Hz}), 3.32$ $(2 \mathrm{H}, \mathrm{t}, J=6.5 \mathrm{~Hz}), 2.02(3 \mathrm{H}, \mathrm{s}), 1.23(3 \mathrm{H}, \mathrm{t}, J=7.0 \mathrm{~Hz})$, $1.22(3 \mathrm{H}, \mathrm{s})$.

The bromo-keto-ester obtained above $(51 \mathrm{~g})$ was dissolved in acetic acid $(60 \mathrm{ml})$ and $47 \%$ hydrobromic acid $(80 \mathrm{ml})$ and refluxed for a day with stirring. The reaction mixture was neutralized with sodium carbonate and extracted with ether. After usual work-up, distillation gave 9-bromo-3-methyl-2-nonanone (II) $(29 \mathrm{~g}, 75 \%)$, bp $112 \sim 118^{\circ} \mathrm{C}(3 \mathrm{mmHg})$. IR $v_{\max }^{\text {fim }} \mathrm{cm}^{-1}: 1710$. NMR $\delta_{\mathrm{TMS}}^{\mathrm{CCl}_{4}}: 3.32(2 \mathrm{H}, \mathrm{t}, J=6.5 \mathrm{~Hz}), 2.34(1 \mathrm{H}$, sextet, $J=$ $6.8 \mathrm{~Hz}), 2.02(3 \mathrm{H}, \mathrm{s}), 1.02(3 \mathrm{H}, \mathrm{d}, J=6.8 \mathrm{~Hz})$.

9-Bromo-2-ethylenedioxy-3-methylnonane (III)

The solution of the bromoketone (II) (31.4 g), ethyl- 
ene glycol (15g), and p-toluene sulfonic acid $(0.5 \mathrm{~g})$ in benzene $(200 \mathrm{ml})$ was refluxed for $24 \mathrm{hr}$ with azeotropic removal of water. The reaction mixture was worked up in an usual manner to give the ketal (III) $(25 \mathrm{~g}, 67 \%)$ as a colorless oil, bp $125 \sim 130^{\circ} \mathrm{C}(3 \mathrm{mmHg})$. NMR $\delta_{\text {TMS }}^{\mathrm{CCl}_{4}}: 3.77(4 \mathrm{H}, \mathrm{s}), 3.29(2 \mathrm{H}, \mathrm{t}, J=6.5 \mathrm{~Hz}), 1.09(3 \mathrm{H}, \mathrm{s})$, $0.85(3 \mathrm{H}, \mathrm{d}, J=6.8 \mathrm{~Hz})$.

\section{1,11-Ethylenedioxy-10-methyl-2-dodecanone (IV)}

To sodium ethoxide solution $(4.5 \mathrm{~g}$ of sodium in $100 \mathrm{ml}$ of abs. ethanol) ethyl acetoacetate $(26 \mathrm{~g})$ was added and refluxed gently for a while and then the bromide (III) $(25 \mathrm{~g})$ was added and heated in an oil bath $\left(45^{\circ} \mathrm{C}\right)$ for two days. The resultant crude product was purified by column chromatography on silica gel $(350 \mathrm{~g})$ which was eluted first with benzene to separate the unreacted materials and then with a mixture of benzene: ether $(50: 1)$ to give ethyl 2-acetyl-10,10-ethylenedioxy9-methylundecanoate $(18 \mathrm{~g}, 60 \%)$ as a colorless oil. IR $\nu_{\max }^{\mathrm{Alm}} \mathrm{cm}^{-1}: 1735,1710$. NMR $\delta_{\mathrm{TMS}}^{\mathrm{CCl}_{4}}: 4.12(2 \mathrm{H}, \mathrm{q}$, $J=7.0 \mathrm{~Hz}), 3.80(4 \mathrm{H}, \mathrm{s}), 3.18(1 \mathrm{H}, \mathrm{t}, J=7.0 \mathrm{~Hz}), 2.10$ $(3 \mathrm{H}, \mathrm{s}), 1.23(3 \mathrm{H}, \mathrm{t}, J=7.0 \mathrm{~Hz}), 1.10(3 \mathrm{H}, \mathrm{s}), 0.85(3 \mathrm{H}$, d, $J=6.8 \mathrm{~Hz}$ ).

The keto ester obtained above $(6.3 \mathrm{~g})$ was dissolved in ethanol $(60 \mathrm{ml})$ containing potassium hydroxide $(3 \mathrm{~g})$ and kept overnight at room temperature, and then refluxed for $3 \mathrm{hr}$ to complete hydrolysis and decarboxylation. The resultant solution was worked up in an usual manner to afford the crude product, which was purified by distillation to collect 11,11-ethylenedioxy10-methyl-2-dodecanone (IV) $(2.5 \mathrm{~g})$, bp $140 \sim 145^{\circ} \mathrm{C}$ $(3 \mathrm{mmHg})$, as a colorless oil. IR $\nu_{\mathrm{max}}^{\mathrm{fl}} \mathrm{cm}^{-1}: 1710$. NMR $\delta_{\mathrm{TMS}}^{\mathrm{CCl}_{4}}: 3.80(4 \mathrm{H}, \mathrm{s}), 2.30(2 \mathrm{H}, \mathrm{t}, J=6.8 \mathrm{~Hz}), 2.01$ $(3 \mathrm{H}, \mathrm{s}), 1.10(3 \mathrm{H}, \mathrm{s}), 0.85(3 \mathrm{H}, \mathrm{d}, J=6.8 \mathrm{~Hz})$.

\section{2,2-Ethylenedioxy-3, 11-dimethyl-29-(2'-tetrahydropyra- nyl)-oxy-1I-nonacosanol (VI)}

This compound was prepared by the reaction of the ketone (IV) with the Grignard reagent of 18-bromohexadecanyl tetrahydropyranyl ether (V). The tetrahydropyranyl ether (V) was obtained conveniently through the following synthetic route. The bifunctional Grignard reagent of 1,12-dibromododecane was coupled with allyl bromide to yield 1,17-octadecadiene, which was subjected to hydroboration followed by oxidative decomposition with alkaline hydrogen peroxide to afford 1,18-octadecanediol in a satisfactory yield.

The diol, however, melted at $87^{\circ} \mathrm{C}$ (lit. ${ }^{7)} 96 \sim 98^{\circ} \mathrm{C}$ ) presumably due to admixture of a small amount of the positional isomers of the diol. Half bromination of the diol was achieved by refluxing in a mixture of conc. sulfuric acid, conc. hydrobromic acid, and heptane for $20 \mathrm{hr}$ with vigorous stirring. The bromohydrine obtained from heptane layer was converted to the tetrahydropyranyl ether $(V)$ according to the conventional procedure.
To the Grignard reagent solution prepared from magnesium $(0.3 \mathrm{~g})$ and the bromohydrine tetrahydropyranyl ether (V) $(4.33 \mathrm{~g})$ in ether $(20 \mathrm{ml})$ the ketone (IV) $(2.56 \mathrm{~g})$ in ether $(20 \mathrm{ml})$ was added dropwise and refluxed for $2 \mathrm{hr}$. The crude product was purified through a silica gel column $(70 \mathrm{~g})$ by eluting with a mixture of benzene: ethyl acetate $(10: 1)$ to give a soft crystalline solid of the tertiary alcohol (VI) $(3.12 \mathrm{~g}$, $51 \%)$. IR $\nu_{\max }^{\mathrm{flm}} \mathrm{cm}^{-1}: 3450$. NMR $\delta_{\mathrm{TMS}}^{\mathrm{CDC1}}: 4.53(1 \mathrm{H}$, $\mathrm{m}), 3.90(4 \mathrm{H}, \mathrm{s}), 4.0 \sim 3.2(4 \mathrm{H}, \mathrm{m}), 1.20(3 \mathrm{H}, \mathrm{s}), 1.11$ $(3 \mathrm{H}, \mathrm{s}), 0.92(3 \mathrm{H}, \mathrm{d}, J=6.8 \mathrm{~Hz})$.

\section{9-Hydroxy-3,11-dimethyl-2-nonacosanone (the com- pound $B)(I b)$}

Ethyl methyl ketone $(100 \mathrm{ml})$ and $p$-toluene sulfonic acid $(0.5 \mathrm{~g})$ were added to the tertiary alcohol (VI) $(1.83 \mathrm{~g})$ and refluxed for $8 \mathrm{hr}$ to result in elimination of the ethylenedioxy group and dehydration. After removal of a half amount of the solvent under reduced pressure, methanol $(70 \mathrm{ml})$ was added and refluxed for additional $4 \mathrm{hr}$ to remove the tetrahydropyranyl group from the molecule. The obtained crude product was purified by chromatography on silica gel column $(45 \mathrm{~g})$ to afford a mixture of isomers of the dehydro-compound B (VII) $(1.06 \mathrm{~g}, 76 \%)$ as an amorphous solid. IR $\nu_{\max }^{\mathrm{film}} \mathrm{cm}^{-1}: 3400,1715$. NMR $\hat{o}_{\mathrm{TMS}}^{\mathrm{CDCl}_{3}}: 5.03(1 \mathrm{H}$, $\mathrm{m}), 3.59(2 \mathrm{H}, \mathrm{t}, J=6.2 \mathrm{~Hz}), 2.45(1 \mathrm{H}, \mathrm{m}), 2.08(3 \mathrm{H}, \mathrm{s})$, 1.63 and 1.54 (3H in total, each broad singlet), 1.04 $(3 \mathrm{H}, \mathrm{d}, J=6.8 \mathrm{~Hz}$ ).

The olefinic compound obtained above (VII) $(0.93 \mathrm{~g})$ was dissolved in a mixture of hexane and ethanol $(1: 1)$ $(50 \mathrm{ml})$ and hydrogenated with platinum oxide $(20 \mathrm{mg})$ to yield the compound $\mathrm{B}(\mathrm{Ib})$, which was purified through a silica gel column and by recrystallization from hexane to give pure compound $(0.56 \mathrm{~g})$ as colorless granules, $m p 40 \sim 41^{\circ} \mathrm{C}$. IR $\nu_{\max }^{\operatorname{alm}} \mathrm{cm}^{-1}: 3400,1715$. NMR $\delta_{T M S}^{\mathrm{CDCl}_{3}}: 3.59(2 \mathrm{H}, \mathrm{t}, \quad J=6.5 \mathrm{~Hz}), 2.45(1 \mathrm{H}$, sextet, $J=6.8 \mathrm{~Hz}), 2.09(3 \mathrm{H}, \mathrm{s}), 1.04(3 \mathrm{H}, \mathrm{d}, J=6.8 \mathrm{~Hz})$, $0.82(3 \mathrm{H}$, broad doublet, $J=6.0 \mathrm{~Hz})$. MS: $m / e 466$ $\left(\mathrm{M}^{+}\right)$. GLC: $R_{t}=17.5 \mathrm{~min}$.

Acknowledgement. We thank Dr. T. Ueno of our institute for mass spectrometric data, and Dr. K. Koshimizu and Miss S. Yamashita of Kyoto University for NMR data.

\section{REFERENCES}

1) R. Nishida, H. Fukami and S. Ishii, Experientia, 30, 978 (1974).

2) R. Nishida, H. Fukami and S. Ishii, Appl. Ent Zool., 10, 10 (1975).

3) R. Nishida, T. Sato, Y. Kuwahara, H. Fukami and S. Ishii, J. Chem. Ecol, 2 (4), (1976), in press.

4) M. Schwarz, J. E. Oliver and P. E. Sonnet, J. Org. Chem., 40, 2410 (1975). 
5) A. W. Burgstahler, L. O. Weigel, W. J. Bell and M. K. Rust, J. Org. Chem., 40, 3456 (1975).

6) T. Sato, R. Nishida, Y. Kuwahara, H. Fukami and S. Ishii, Agr. Biol. Chem., 40, 391 (1976).

7) W. H. Carothers and W. L. McEwen, Org. Synth., 14, 22 (1934). 